\title{
Extraction of Parquat from Blood by Clinoptilolite
}

\author{
Mohammad-Amin Aghaii-Afshar' ${ }^{1}$ and Seyed Vahid Shetab-Boushehri ${ }^{2,3}$ \\ ${ }^{1}$ Department of Medical Nanotechnology, Pharmaceutical Sciences Branch, Islamic Azad University, Tehran 1941 93311, Iran \\ ${ }^{2}$ Department of Medical Nanotechnology, School of Medicine, Iran University of Medical Sciences, P.O. Box 14155-5983, \\ Tehran 14496 14535, Iran \\ ${ }^{3}$ Razi Drug Research Center, Iran University of Medical Sciences, P.O. Box 14155-5983, Tehran 14496 14535, Iran
}

Correspondence should be addressed to Seyed Vahid Shetab-Boushehri; shetab.v@iums.ac.ir

Received 9 June 2014; Accepted 23 July 2014; Published 19 August 2014

Academic Editor: Defeng Wu

Copyright (c) 2014 M.-A. Aghaii-Afshar and S. V. Shetab-Boushehri. This is an open access article distributed under the Creative Commons Attribution License, which permits unrestricted use, distribution, and reproduction in any medium, provided the original work is properly cited.

\begin{abstract}
Paraquat is a bipyridyl herbicide and organic divalent cation which due to its high polarity and water solubility cannot be readily extracted by common organic solvents from body fluids. Dithionite color test for qualitative and quantitative determination of paraquat in urine has been proposed and used for many years. Although some methods were proposed for solvent extraction of paraquat from blood, they are less practical in clinical laboratories and lack high extraction recovery. Clinoptilolite is a highly porous natural zeolite with cation-exchange property and high surface area. In the present work, extraction of paraquat from human blood by clinoptilolite was investigated and compared with Amberlite CG-50 I, a well-known weak cation-exchanger. Blood paraquat was adsorbed by adsorbents (clinoptilolite or Amberlite) and extracted from them by saturated sodium chloride solution. Extracted paraquat was spectrophotometrically measured by means of sodium dithionite reagent at $394.5 \mathrm{~nm}$. Recovery, limit of detection, considering signal-to-noise $(S / N)$ ratio of 3 , and limit of quantification, regarding $S / N$ of 10 , of paraquat extraction by clinoptilolite and Amberlite CG-50 were $81.7 \% \pm 3.4 \%, 0.58 \mu \mathrm{g}$, and $1.93 \mu \mathrm{g}$ and $83.6 \% \pm 3.2 \%, 0.49 \mu \mathrm{g}$, and $1.63 \mu \mathrm{g}$, respectively. Repeatabilities (within-laboratory error) of paraquat extraction by clinoptilolite and Amberlite CG-50 I were 7.1\% and 6.3\%, respectively.
\end{abstract}

\section{Introduction}

Paraquat, $1,1^{\prime}$-Dimethyl-4,4'-bipyridinium, is a bipyridyl herbicide and divalent organic cation [1] which due to its high polarity and water solubility cannot be readily extracted by common organic solvents from body fluids [2]. Dithionite color test for qualitative and quantitative determination of paraquat in urine has been proposed and used for many years [3]. Although some methods were proposed for solvent extraction of paraquat from blood [4, 5], they are less practical in clinical laboratories and lack high extraction recovery. Zeolites are microporous hydrated aluminosilicate materials which are available as naturally occurring materials or as synthetically manufactured substances [6]. They are used in industries and medicine for their high surface area/volume ratio. Clinoptilolite as a natural zeolite due to its high availability, low cost, and high surface area/volume ratio has found many applications in agriculture $[7,8]$, animal husbandry [9], industries $[8,10]$, and medicine [11-16]. It has been found to be an efficient adsorbent of cations [10, 17] and a nontoxic carrier for drugs [11]. It has high negative charge which is distributed through its internal and external surface area. In the present work, solid-phase extraction of paraquat from human blood by clinoptilolite was investigated and compared with Amberlite CG-50 I, a well-known weak cation-exchanger.

\section{Materials and Methods}

Paraquat dichloride (Riedel-deHaën, Germany), micronized (particle size $\leq 37 \mu \mathrm{m})$ Iranian clinoptilolite (Anzymite) powder (Afrand Tooska, Tehran, Iran), Amberlite CG-50 I (Merck, Germany), sodium dithionite (Merck, Germany), sodium hydroxide (Merck, Germany), sodium chloride (Merck, Germany), methanol (Merck, Germany), and stainless steel mesh sieves (800 and 400 mesh equivalent to 16 
and $37 \mu \mathrm{m}$ opening diameters, resp.) (Anping County Resen Screen Co., Hengshui, China) were used in the present work.

Firstly, clinoptilolite powder with particle size of 11$40 \mu \mathrm{m}$ was prepared by suspending micronized clinoptilolite powder (particle size $\leq 37 \mu \mathrm{m}$ ) in distilled water (DW) followed by passing the suspension from 400 mesh (equivalent to $37 \mu \mathrm{m}$ openings diameters) stainless steel sieve. The passed fraction of powder was passed from 800 mesh (equivalent to $16 \mu \mathrm{m}$ openings diameters) stainless steel sieve. Retained fraction of clinoptilolite by 800 mesh sieve was used in the present study. Before use, the sieved fraction was washed several times with DW, centrifuged at $5000 \mathrm{rpm}$, and dried in an oven at $250^{\circ} \mathrm{C}$ for $24 \mathrm{hrs}$ [17].

Particle size and zeta potential of a $0.5 \%(\mathrm{w} / \mathrm{v})$ suspension of sieved clinoptilolite in DW were determined by a particle size analyzer (Mastersizer Hydro 2000S, Malvern Instruments Ltd., UK) and a Zetasizer (Nano ZS, Malvern Instruments Ltd., UK), respectively. The $\mathrm{pH}$ of the sieved clinoptilolite suspension was 9.5 due to inherent basicity of clinoptilolite. Zeta potential was measured to show a cationexchange property of clinoptilolite.

Sieved clinoptilolite was photographed by a fieldemission scanning electron microscope (FE-SEM) (Hitachi, Model S-4160, Japan) to study the morphology and crystallinity of clinoptilolite particles. Specific surface of sieved clinoptilolite was also determined by Nano SORD (Toseye Hesgarsazan Asia Co., Iran). A BET (Brunauer, Emmett, Teller) isotherm was used to measure specific surface of sieved clinoptilolite. Sieved clinoptilolite was firstly degassed at $350^{\circ} \mathrm{C}$ for 3 hours and then specific surface was determined at $298.00 \mathrm{~K}\left(24.85^{\circ} \mathrm{C}\right)$ by nitrogen gas as adsorbate.

Calibration curve of paraquat dichloride in distilled water (DW) was constructed as follows: different concentrations (working solutions) of paraquat dichloride (0 (blank), 2, $5,10,15$, and $20 \mu \mathrm{g} / \mathrm{mL}$ ) in DW were prepared from a $1000 \mu \mathrm{g} / \mathrm{mL}$ stock solution of paraquat dichloride in DW. To one $\mathrm{mL}$ of these solutions, one $\mathrm{mL}$ of dithionite reagent (a freshly prepared $0.1 \%(\mathrm{w} / \mathrm{v})$ solution of sodium dithionite in $1 \mathrm{M}$ sodium hydroxide) was separately added and their ultraviolet (UV) absorbances at $394.5 \mathrm{~nm}$ were read versus blank. UV absorbances were then depicted versus respective concentrations. This experiment was repeated 3 times and the best fitted curve was passed through data points. This calibration curve was used to determine the concentration of extracted paraquat from aqueous solution by clinoptilolite and Amberlite CG-50 I.

Calibration curve of paraquat dichloride in human blood was constructed as follows: $6 \mathrm{~mL}$ fresh heparinized human blood was divided into $1 \mathrm{~mL}$ aliquots. Appropriate amounts of a $1000 \mu \mathrm{g} / \mathrm{mL}$ solution of paraquat dichloride in DW were added to them to produce 0 (blank), 2, 5, 10, 15, and $20 \mu \mathrm{g} / \mathrm{mL}$ of paraquat dichloride, respectively. To one $\mathrm{mL}$ of each sample, one $\mathrm{mL}$ of methanol was added to precipitate protein content of blood. Samples were then centrifuged at $5000 \mathrm{rpm}$ for $5 \mathrm{~min}$. To one $\mathrm{mL}$ of each supernatant, one $\mathrm{mL}$ of dithionite reagent (a freshly prepared $0.1 \%(\mathrm{w} / \mathrm{v})$ solution of sodium dithionite in $1 \mathrm{M}$ sodium hydroxide) was added except blank tube to which one $\mathrm{mL}$ of $1 \mathrm{M}$ sodium hydroxide was added. Supernatant of the sample containing $2 \mu \mathrm{g} / \mathrm{mL}$ of paraquat dichloride was spectrophotometrically scanned between 400 and $800 \mathrm{~nm}$. The UV absorbance maximum at $394.5 \mathrm{~nm}$ was used for quantitative measurements. UV absorbances were depicted versus respective concentrations. This experiment was repeated 3 times and the best fitted curve was passed through data points. This calibration curve was used to determine the concentration of extracted paraquat from blood by clinoptilolite and Amberlite CG-50 I. It was also used for determination of extraction recovery of paraquat from blood by division of absorbances of respective concentrations in this calibration curve into those of aqueous solutions. The results were then multiplied by 2 (dilution factor) and mean and standard deviation of them were calculated.

Extraction of paraquat from aqueous solution by Amberlite CG-50 I was done as follows: one gram of Amberlite CG50 I was washed three times with DW. $5 \mathrm{~mL}$ of DW containing $20 \mu \mathrm{g}$ paraquat dichloride was added to washed Amberlite, vortexed for $15 \mathrm{~min}$, and centrifuged at $5000 \mathrm{rpm}$ for $5 \mathrm{~min}$. To one $\mathrm{mL}$ of supernatant, one $\mathrm{mL}$ of dithionite reagent was added and UV absorbance at $394.5 \mathrm{~nm}$ was recorded versus dithionite reagent as blank. Amount of adsorbed paraquat by Amberlite particles was determined by the interpolation of UV absorption of supernatant at $394.5 \mathrm{~nm}$ over paraquat tabulated concentrations on respective calibration curve followed by multiplication of resulting concentration by respective volume of supernatant and subtraction from original paraquat amount $(20 \mu \mathrm{g})$. For extraction (desorption) of adsorbed paraquat, supernatant was discarded and one $\mathrm{mL}$ of saturated sodium chloride solution in DW was added to the precipitate followed by $15 \mathrm{~min}$ vortex and later centrifugation at $5000 \mathrm{rpm}$ for $5 \mathrm{~min}$. To one $\mathrm{mL}$ of supernatant, one $\mathrm{mL}$ of dithionite reagent was added and UV absorbance at $394.5 \mathrm{~nm}$ was recorded versus dithionite reagent as blank. Amount of extracted (desorbed) paraquat from Amberlite particles was determined by interpolation of UV absorption of supernatant at $394.5 \mathrm{~nm}$ over paraquat tabulated concentrations on respective calibration curve followed by multiplication of resulting concentration by respective volume of supernatant. This experiment was repeated 5 times. Recovery of extraction was calculated by division of extracted paraquat value into initial paraquat amount $(20 \mu \mathrm{g})$. Limit of detection (LOD), considering signal-to-noise $(S / N)$ ratio of 3 , limit of quantification (LOQ), regarding $S / N$ of 10 , and repeatability (within-laboratory error, WLE) of paraquat extraction were also calculated as previously described [18].

Extraction of paraquat from aqueous solution by clinoptilolite was exactly done as for Amberlite CG-50 I.

Extraction of paraquat from blood by Amberlite CG50 I was done as follows: one gram of Amberlite CG-50 I was separately added to two test tubes labeled as test and blank. Content of each tube was washed three times with DW followed by centrifugation at $5000 \mathrm{rpm}$ for $5 \mathrm{~min}$; supernatants were discarded. $5 \mathrm{~mL}$ of fresh heparinized human blood, containing $20 \mu \mathrm{g}$ paraquat, was separately added to two test tubes labeled as test and blank. $5 \mathrm{~mL}$ methanol was separately added to each tube and mixed gently followed by centrifugation at $5000 \mathrm{rpm}$ for $5 \mathrm{~min}$. 
Supernatant of each tube was added to respective tube containing washed Amberlite followed by 15 min vortex and later by centrifugation at $5000 \mathrm{rpm}$ for $5 \mathrm{~min} .1 \mathrm{~mL}$ dithionite reagent was added to $1 \mathrm{~mL}$ of supernatant of test tube while to $1 \mathrm{~mL}$ of supernatant of blank tube $1 \mathrm{~mL}$ of $1 \mathrm{M}$ sodium hydroxide solution in DW was added. UV absorbance of test solution was read versus blank solution at $394.5 \mathrm{~nm}$. Amount of adsorbed paraquat by Amberlite particles was determined by interpolation of UV absorption of supernatant at $394.5 \mathrm{~nm}$ over paraquat tabulated concentrations on respective calibration curve followed by multiplication of resulting concentration by respective volume of supernatant and subtraction from original paraquat amount $(20 \mu \mathrm{g})$. For extraction (desorption) of adsorbed paraquat, supernatant was discarded and $1 \mathrm{~mL}$ of saturated sodium chloride solution in DW was added to precipitate of each tube followed by $15 \mathrm{~min}$ vortex and later centrifugation at $5000 \mathrm{rpm}$ for $5 \mathrm{~min}$. $1 \mathrm{~mL}$ dithionite reagent was added to $1 \mathrm{~mL}$ of supernatant of test tube while to $1 \mathrm{~mL}$ of supernatant of blank tube was added $1 \mathrm{~mL}$ of $1 \mathrm{M}$ sodium hydroxide solution in DW. UV absorbance of test solution was read versus blank solution at $394.5 \mathrm{~nm}$. Amount of extracted (desorbed) paraquat from Amberlite particles was determined by interpolation of UV absorption of supernatant at $394.5 \mathrm{~nm}$ over paraquat tabulated concentrations on respective calibration curve followed by multiplication of resulting concentration by respective volume of supernatant. This experiment was repeated 5 times. Recovery of extraction was calculated by division of extracted paraquat value into initial paraquat amount $(20 \mu \mathrm{g})$ followed by multiplication of resulting value by extraction recovery of paraquat from blood by methanol. LOD, considering signalto-noise $(S / N)$ ratio of $3, L O Q$, regarding $S / N$ of 10 , and WLE of paraquat extraction were also calculated as previously described [18].

Extraction of paraquat from blood by clinoptilolite was exactly done as for Amberlite CG-50 I.

Difference between percentages of extraction recovery of paraquat from aqueous solutions by Amberlite and clinoptilolite was statistically analyzed by Student $t$-test. Also, differences of percentages of extraction recovery of paraquat from blood by methanol, Amberlite, and clinoptilolite from 100 (maximum extraction recovery) were statistically analyzed by separate one-sample $t$-tests. One-way analysis of variance (ANOVA) with Scheffe post hoc was used to test statistical differences between extraction recovery values of paraquat from blood by methanol, Amberlite, and clinoptilolite. The statistical analyses were done on SPSS 19 statistical package. $P$ values less than 0.05 were statistically considered significant.

\section{Results}

Particle size $(11-40 \mu \mathrm{m})$ and zeta potential $(-27.9 \mathrm{mV})$ of sieved clinoptilolite were shown in Figures 1 and 2, respectively.

BET of sieved clinoptilolite was $33.79 \mathrm{~m}^{2} / \mathrm{g}$. FE-SEM photomicrograph of sieved clinoptilolite was shown in Figure 3. Sieved clinoptilolite shows some degrees of crystallinity. In fact, it shows a semicrystalline morphology.

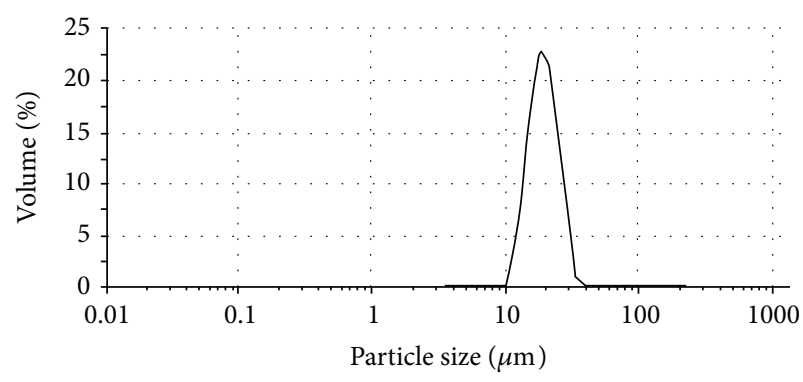

FIgURE 1: Particle size distribution of sieved clinoptilolite.

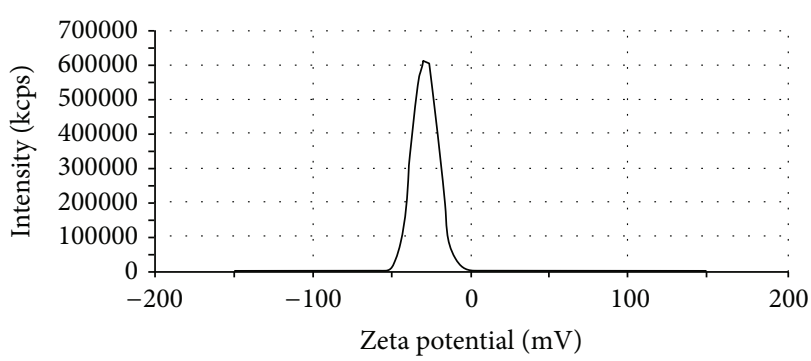

FIgURE 2: Zeta potential curve of sieved clinoptilolite.

UV spectrum of a $10 \mu \mathrm{g} / \mathrm{mL}$ aqueous solution of paraquat was shown in Figure 4.

UV-visible spectrum of this solution when reacted with dithionite reagent in a 1:1 ratio was shown in Figure 5.

UV-visible spectrum of a methanolic extract of blood containing $2 \mu \mathrm{g} / \mathrm{mL}$ paraquat when reacted with dithionite reagent was shown in Figure 6.

Paraquat calibration curves in aqueous solution and blood when solutions were reacted with dithionite reagent were shown in Figures 7 and 8, respectively.

Recovery of extraction, LOD, LOQ, and WLE of paraquat extraction by methanol, Amberlite, and clinoptilolite from different matrices were shown in Table 1.

As it is shown in Table 1 , no statistical difference $(P$ value $=0.994)$ was seen between percentages of recovery of paraquat extraction by Amberlite and clinoptilolite from aqueous solutions. Recovery of paraquat extraction from blood by methanol $(P$ value $=0.007)$, Amberlite $(P$ value $=$ $0.012)$, and clinoptilolite $(P$ value $=0.011)$ was significantly lower than maximum extraction recovery of 100. Extraction recovery of paraquat from blood by Amberlite $(P$ value $=$ $0.700)$ and clinoptilolite $(P$ value $=0.323)$ was not statistically different from that by methanol. No statistical difference $(P$ value $=0.745$ ) was also seen between percentages of recovery of paraquat extraction by Amberlite and clinoptilolite from blood samples.

\section{Discussion}

High extraction recovery of paraquat from blood, regardless of the analytical method used, has been a concern in analytical toxicology. Although qualitative as well as quantitative determination of paraquat in urine by dithionite reagent has been routinely used in hospital toxicology for many years 
TABLE 1: Recovery, limit of detection, limit of quantification, and within-laboratory error of paraquat extraction by Amberlite and clinoptilolite from different matrices.

\begin{tabular}{|c|c|c|c|c|c|}
\hline $\begin{array}{l}\text { Experiment } \\
\text { number }\end{array}$ & $\begin{array}{l}\text { Experimental } \\
\text { group }\end{array}$ & $\begin{array}{l}\text { \% recovery } \\
(\text { mean } \pm \mathrm{sd})\end{array}$ & $\begin{array}{c}\text { LOD } \\
(\mu \mathrm{g} / \mathrm{mL})\end{array}$ & $\begin{array}{c}\text { LOQ } \\
(\mu \mathrm{g} / \mathrm{mL})\end{array}$ & $\begin{array}{c}\text { Repeatability } \\
\text { (\%RSD) }\end{array}$ \\
\hline 1 & $\begin{array}{l}\text { Extraction of paraquat from blood by } \\
\text { methanol }\end{array}$ & $85.7 \pm 2.1^{*}$ & 0.91 & 3.03 & 2.4 \\
\hline 2 & $\begin{array}{l}\text { Extraction of paraquat from aqueous } \\
\text { solution by Amberlite }\end{array}$ & $98.3 \pm 2.7$ & 0.34 & 1.13 & 3.5 \\
\hline 3 & $\begin{array}{l}\text { Extraction of paraquat from aqueous } \\
\text { solution by clinoptilolite }\end{array}$ & $97.2 \pm 3.1$ & 0.43 & 1.43 & 4.3 \\
\hline 4 & $\begin{array}{c}\text { Extraction of paraquat from blood by } \\
\text { Amberlite }\end{array}$ & $83.6 \pm 3.2^{*}$ & 0.49 & 1.63 & 6.3 \\
\hline 5 & $\begin{array}{c}\text { Extraction of paraquat from blood by } \\
\text { clinoptilolite }\end{array}$ & $81.7 \pm 3.4^{*}$ & 0.58 & 1.93 & 7.1 \\
\hline
\end{tabular}

LOD: limit of detection; LOQ: limit of quantification; WRE: within-laboratory error; RSD: relative standard deviation. ${ }^{*}$ Significantly $(P$ value $<0.05)$ lower than maximum extraction recovery of 100 .

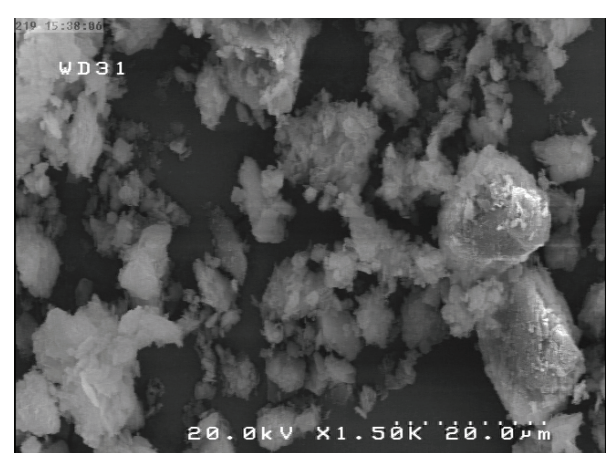

FIGURE 3: FE-SEM photomicrograph of sieved clinoptilolite.

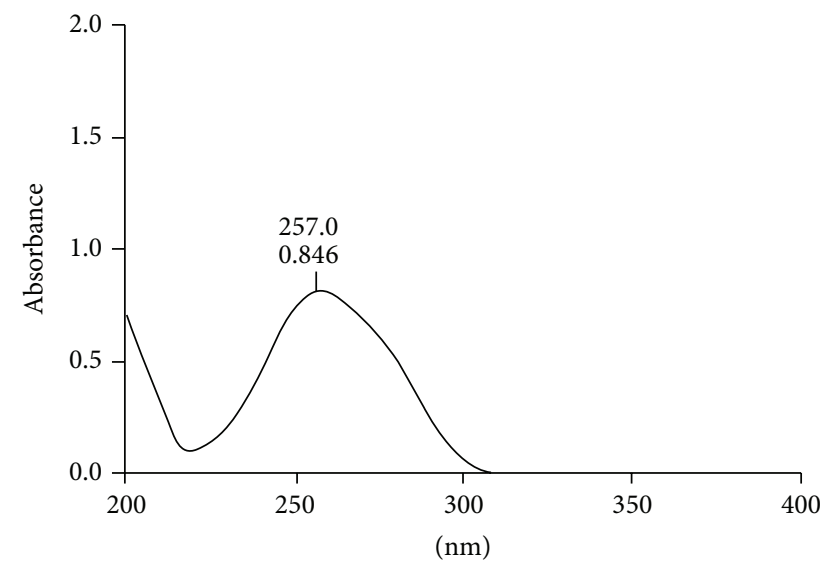

FIGURE 4: UV spectrum of a $10 \mu \mathrm{g} / \mathrm{mL}$ aqueous solution of paraquat.

[3], due to a relationship between paraquat blood level and severity of its toxicity, quantitative determination of paraquat in blood has still kept its importance in clinic [19-21].

Liquid-liquid extraction (LLE) methods have been proposed for extraction of paraquat from urine and blood, but they lack high recovery due to high polarity and water solubility of paraquat $[4,5]$. Solid-phase extraction (SPE) is gradually replacing the traditional LLE method in

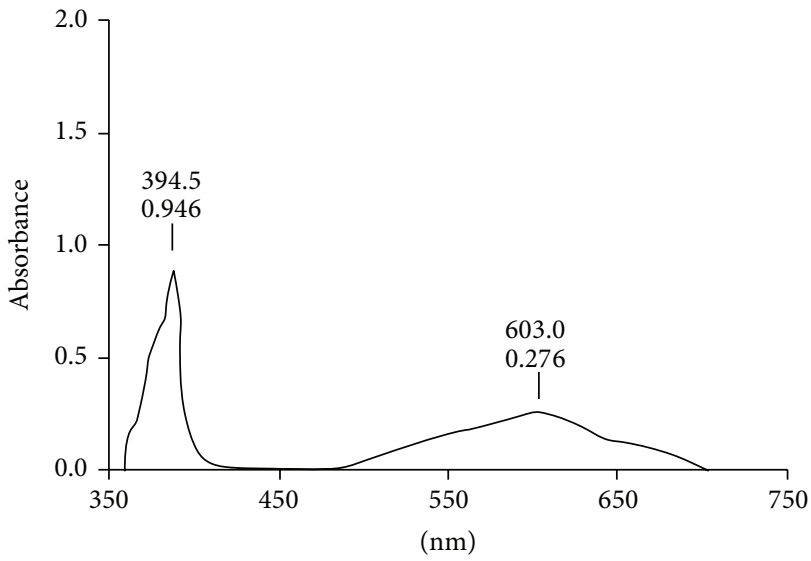

FIGURE 5: UV-visible spectrum of a $10 \mu \mathrm{g} / \mathrm{mL}$ aqueous solution of paraquat when reacted in a $1: 1$ ratio with dithionite reagent.

the extraction of drugs and poisons from biological and nonbiological materials. It can be used for three important purposes in up-to-date analyses, including concentrating of the analyte, removing interfering substances, and changing the matrix of the analyte as needed for subsequent analyses. SPE has several advantages over LLE such as low solvent consumption, enormous saving of time, increased extraction efficiency, decreased evaporation volumes, higher selectivity, cleaner extracts, greater reproducibility, avoidance of emulsion formation, and easier automation [22]. SPE has been successfully used for the extraction of paraquat from biological materials $[2,23,24]$.

It has been shown that clinoptilolite has a cationexchange capacity of $1.4-1.6 \mathrm{mEq} / \mathrm{g}$ [25]. So, it is considered a weak cation-exchange substance. Zeta potential is a measure of particle surface charge. A negative zeta potential indicates a negative surface charge of particles. The measured zeta potential of sieved clinoptilolite $(-27.9 \mathrm{mV})$ in DW showed a slight cation-exchange property of clinoptilolite. Amberlite CG-50 I, a well-known weak cation-exchanger, has a cationexchange capacity of $10 \mathrm{mEq} / \mathrm{g}$. Thus, it is estimated that each 


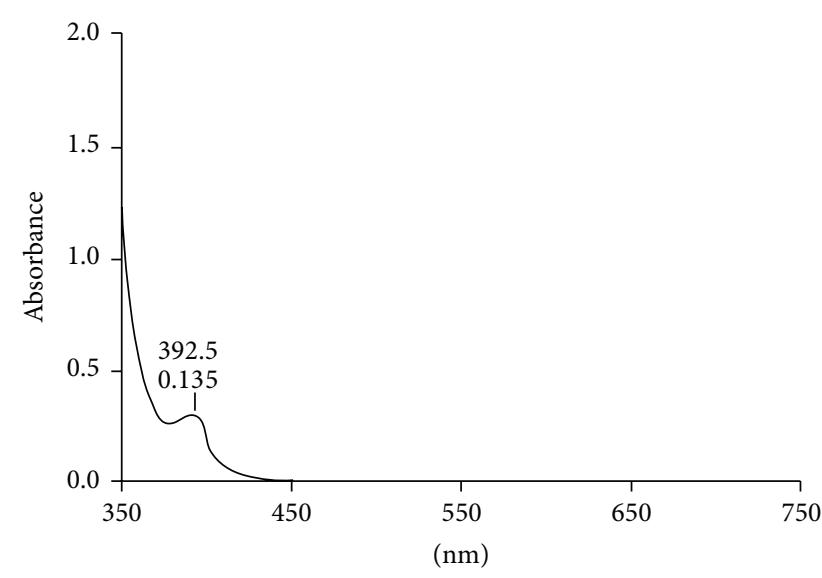

FIgURE 6: UV-visible spectrum of a methanolic extract of blood containing $2 \mu \mathrm{g} / \mathrm{mL}$ paraquat, when reacted in a $1: 1$ ratio with dithionite reagent.

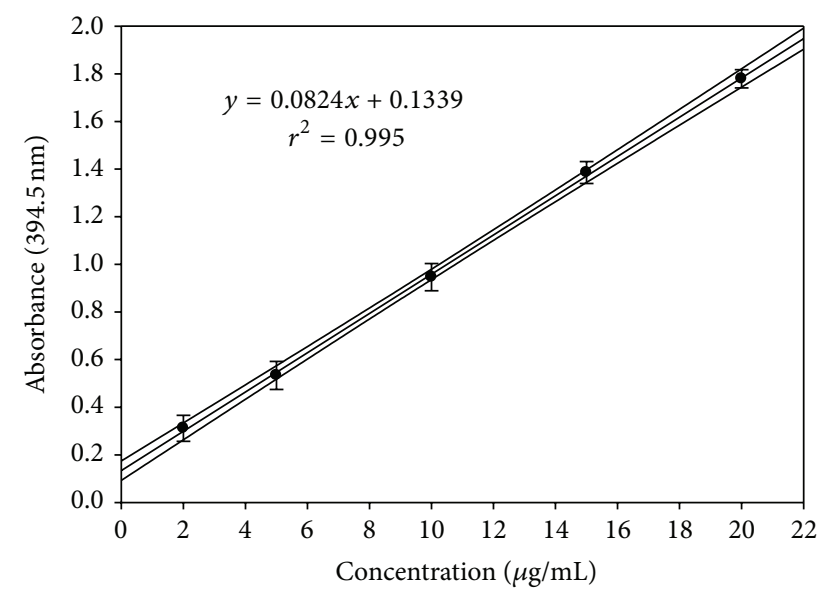

Figure 7: Paraquat calibration curve in aqueous solution when reacted with dithionite reagent.

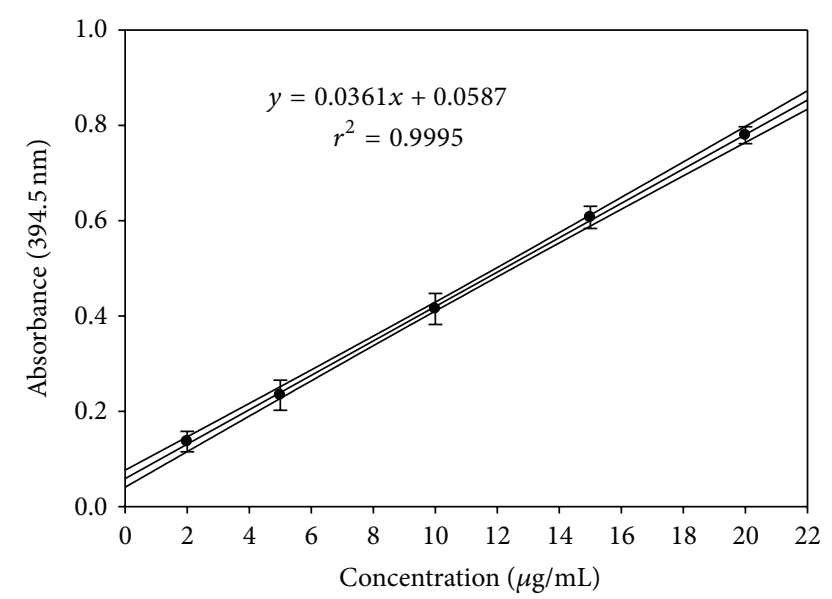

FIGURE 8: Paraquat calibration curve in blood when reacted with dithionite reagent. gram of Amberlite CG-50 I and clinoptilolite can extract about $931.5 \mathrm{mg}$ and $130.4-149.0 \mathrm{mg}$ of paraquat, respectively. Paraquat blood concentrations greater than about $2 \mathrm{mg} / \mathrm{L}$ and $0.1 \mathrm{mg} / \mathrm{L}$ at $4 \mathrm{~h}$ and $24 \mathrm{~h}$ postingestion, respectively, are lethal in most subjects. Thus, it seems that both Amberlite CG-50 I and clinoptilolite are good extractors of paraquat from blood.

The present work shows no statistical difference between percentages of extraction recovery of paraquat by Amberlite and clinoptilolite from blood samples. On the other hand, Amberlite has been used for extraction of paraquat [26]. Thus, clinoptilolite as a high available and low cost natural substance with high specific surface area is proposed as an alternative for the extraction of paraquat from blood. Moreover, the present work shows that paraquat extraction from blood by methanol has a high recovery rate $(85.7 \pm 2.1 \%)$. Thus, extraction of paraquat from blood by methanol as well as further spectrophotometric determination by dithionite reagent is proposed for routine quantitative determination of paraquat in blood. If lower LOD is needed, Amberlite or clinoptilolite is proposed for this purpose.

\section{Conclusion}

The obtained results show that natural clinoptilolite should be used effectively for the extraction of paraquat from water solution and blood. The high extraction efficiency of paraquat from water solution and blood $(98 \%$ and $82 \%$, resp.) by availability and low cost clinoptilolite is close to the extraction efficiency obtained for Amberlite (98\% and 82\%, resp.). It seems that clinoptilolite could also be useful for gastrointestinal decontamination of paraquat.

\section{Conflict of Interests}

The authors declare that there is no conflict of interests regarding the publication of this paper.

\section{Acknowledgment}

The authors gratefully thank Afrand Tooska Co. for supplying micronized clinoptilolite powder (Anzymite) used in the present work.

\section{References}

[1] P. M. Rappold, M. Cui, A. S. Chesser et al., "Paraquat neurotoxicity is mediated by the dopamine transporter and organic cation transporter-3," Proceedings of the National Academy of Sciences of the United States of America, vol. 108, no. 51, pp. 20766-20771, 2011.

[2] K. B. Seung, S. S. Young, S. C. Hee, and Y. P. Myoung, "Comparison study of the extraction methods of paraquat in post-mortem human blood samples," Archives of Pharmacal Research, vol. 30, no. 2, pp. 235-239, 2007.

[3] D. J. Berry and J. Grove, "The determination of paraquat $\left(1,1^{\prime}\right.$ dimethyl-4,4'-bipyridylium cation) in urine," Clinica Chimica Acta, vol. 34, no. 1, pp. 5-11, 1971.

[4] D. R. Jarvie and M. J. Stewart, "The rapid extraction of paraquat from plasma using an ion-pairing technique," Clinica Chimica Acta, vol. 94, no. 3, pp. 241-251, 1979. 
[5] T. Matsuoka and J. Okuda, "Extraction and quantitation of paraquat and diquat from blood," Forensic Science International, vol. 62 , no. 3, pp. 179-186, 1993.

[6] D. S. Coombs, A. Alberti, T. Armbruster et al., "Recommended nomenclature for zeolite minerals: report of the subcommittee on zeolites of the International Mineralogical Association, commission on new minerals and mineral names," Canadian Mineralogist, vol. 35, no. 6, pp. 1571-1606, 1997.

[7] E. Polat, M. Karaca, H. Demir, and A. N. Onus, "Use of natural zeolite (clinoptilolite) in agriculture," Journal of Fruit and Ornamental Plant Research, vol. 12, pp. 183-189, 2004.

[8] F. A. Mumpton, "La roca magica: uses of natural zeolites in agriculture and industry," Proceedings of the National Academy of Sciences of the United States of America, vol. 96, no. 7, pp. 3463-3470, 1999.

[9] D. A. Ural, O. Cengiz, K. Ural, and S. Ozaydin, "Dietary clinoptilolite addition as a factor for the improvement of milk yield in dairy cows," Journal of Animal and Veterinary Advances, vol. 12, no. 1, pp. 85-87, 2013.

[10] G. Kocasoy and V. Şahin, "Heavy metal removal from industrial wastewater by clinoptilolite," Journal of Environmental Science and Health-Part A, vol. 42, no. 14, pp. 2139-2146, 2007.

[11] T. Farías, A. R. Ruiz-Salvador, and A. Rivera, "Interaction studies between drugs and a purified natural clinoptilolite," Microporous and Mesoporous Materials, vol. 61, no. 1-3, pp. 117125, 2003.

[12] N. Zarkovic, K. Zarkovic, M. Kralj et al., "Anticancer and antioxidative effects of micronized zeolite clinoptilolite," Anticancer Research, vol. 23, no. 2, pp. 1589-1595, 2003.

[13] K. Pavelic, M. Katic, V. Sverko et al., "Immunostimulatory effect of natural clinoptilolite as a possible mechanism of its antimetastatic ability," Journal of Cancer Research and Clinical Oncology, vol. 128, no. 1, pp. 37-44, 2002.

[14] K. Pavelić, M. Hadžija, L. Bedrica et al., "Natural zeolite clinoptilolite: new adjuvant in anticancer therapy," Journal of Molecular Medicine, vol. 78, no. 12, pp. 708-720, 2001.

[15] M. Grce and K. Pavelić, "Antiviral properties of clinoptilolite," Microporous and Mesoporous Materials, vol. 79, no. 1-3, pp. 165169, 2005.

[16] G. Rodríguez-Fuentes, M. A. Barrios A Iraizoz, I. Perdomo, and B. Cedré, "Enterex: anti-diarrheic drug based on purified natural clinoptilolite," Zeolites, vol. 19, no. 5-6, pp. 441-448, 1997.

[17] S. Koh and J. B. Dixon, "Preparation and application of organominerals as sorbents of phenol, benzene and toluene," Applied Clay Science, vol. 18, no. 3-4, pp. 111-122, 2001.

[18] S. V. Shetab Boushehri, M. Tamimi, and A. Kebriaeezadeh, "Quantitative determination of 3,4-methylenedioxymethamphetamine by thin-layer chromatography in ecstasy illicit pills in Tehran," Toxicology Mechanisms and Methods, vol. 19, no. 9, pp. 565-569, 2009.

[19] A. T. Proudfoot, M. S. Stewart, T. Levitt, and B. Widdop, "Paraquat poisoning: significance of plasma-paraquat concentrations," The Lancet, vol. 2, no. 8138, pp. 330-332, 1979.

[20] T. B. Hart, A. Nevitt, and A. Whitehead, "A new statistical approach to the prognostic significance of plasma paraquat concentrations," The Lancet, vol. 2, no. 8413, pp. 1222-1223, 1984.

[21] J. M. Scherrmann, P. Houze, C. Bismuth, and R. Bourdon, "Prognostic value of plasma and urine paraquat concentration," Human \& Experimental Toxicology, vol. 6, no. 1, pp. 91-93, 1987.

[22] R. D. McDowall, "Sample preparation for biomedical analysis," Journal of Chromatography-Biomedical Applications, vol. 492, pp. 3-58, 1989.
[23] Z. Wang and J. Xing, "The quantitative analysis of paraquat in biological samples by liquid chromatography-electrospray ionization-mass spectrometry," Journal of Analytical Toxicology, vol. 35, no. 23, pp. 23-27, 2011.

[24] T. L. Kuo, "Determination of paraquat in biologic materials by a simplified solid phase extraction and spectrophotometry," Journal of the Formosan Medical Association, vol. 94, no. 5, pp. 243-247, 1995.

[25] R. T. Pabalan and F. P. Bertetti, "Cation-exchange properties of natural zeolites," Reviews in Mineralogy and Geochemistry, vol. 45, no. 1, pp. 453-518, 2001.

[26] A. Kuntom, H. Kifli, and Y. A. Tan, "Method for determination of paraquat residue in oil matrix," Journal of Oil Palm Research, vol. 2, no. 2, pp. 57-62, 1999. 

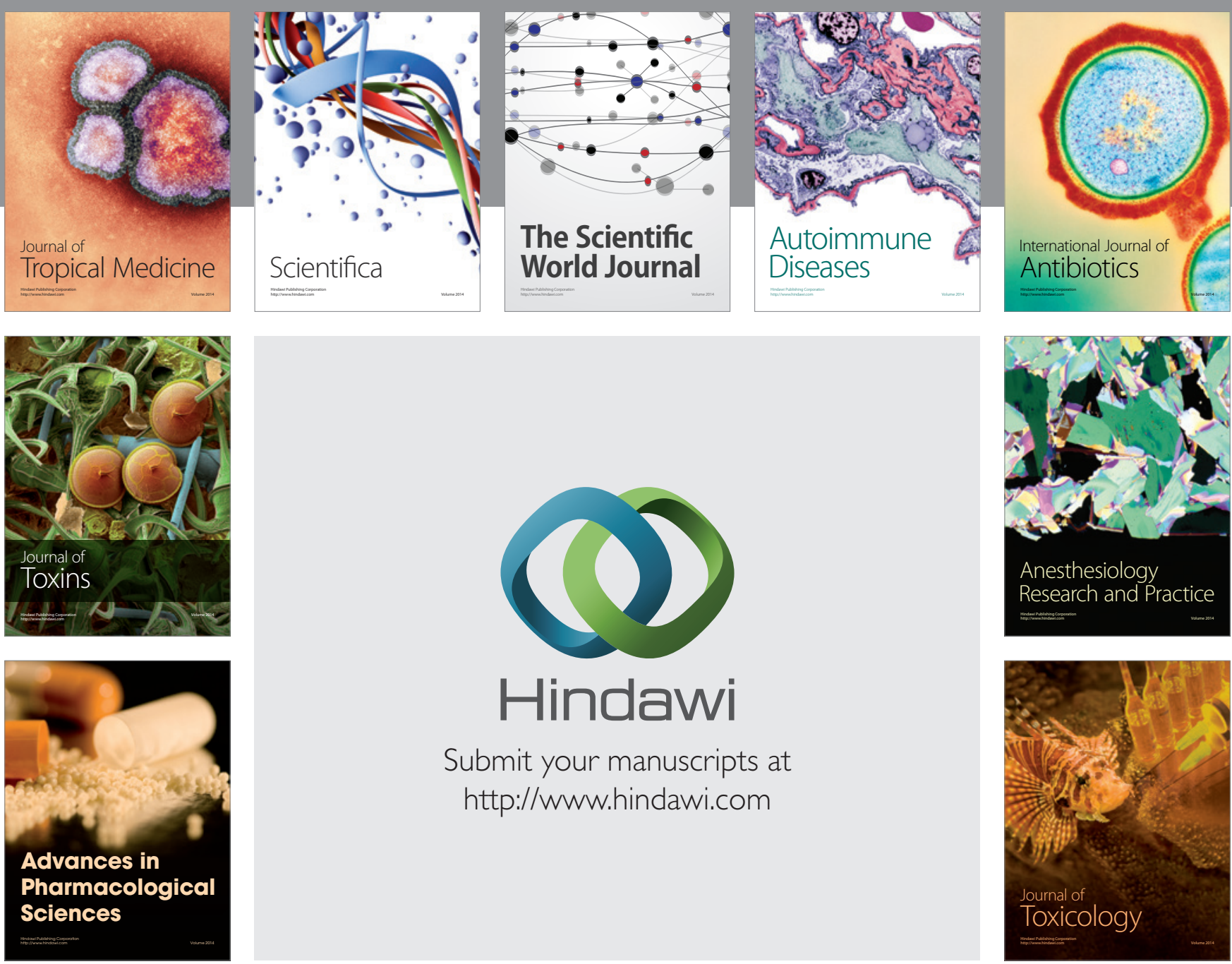

\section{Hindawi}

Submit your manuscripts at

http://www.hindawi.com
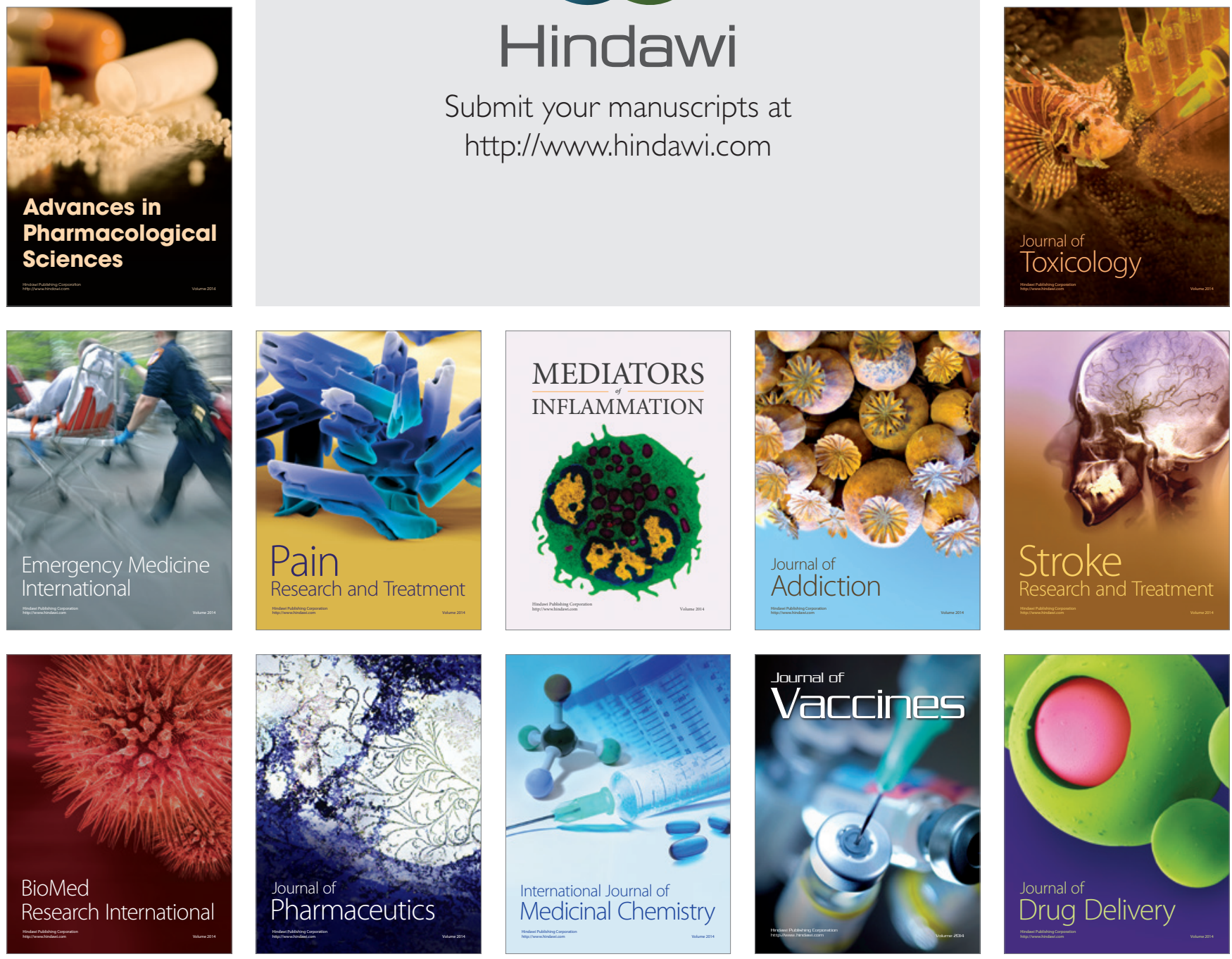